\title{
Environmental and Cultural Dynamics in Nutrition: A Comparison of Food Patterns in Two Nigerian Societies
}

\author{
Abiodun J. Oluwabamide* and Nseabasi S. Akpan** \\ *Department of Sociology, Ahmadu Bello University, Zaria, Nigeria \\ E-mail: abioduntoluwa@yahoo.com \\ **Department of Sociology/Anthropology, University of Uyo, Akwa- Ibom state, Nigeria
}

KEYWORDS Food-Pattern. Culture. Environment. Gari. Fufu

\begin{abstract}
This study examines two societies in Southern Nigeria with a view to determining the extent to which their food patterns are similar. Data were collected from the two societies - Yoruba and Ibibio- both of which are in South-western and South-eastern Nigeria respectively. Both the interview and observation methods were used in data collection. A total of 240 randomly selected interviewees were carefully interviewed. The data revealed that though the two communities share similar environments their food patterns differ a great deal. It is suggested that culture should be taken into consideration when issues related to nutrition are being considered.
\end{abstract}

\section{INTRODUCTION}

Foods are "gifts" of nature; human beings only cultivate the crops and rear or hunt for the animals as the case may be. The types of food eaten in any society depend to a larger extent, on the plants and/or crops and animals, available in the environment. Though through trade and other means food crops not grown in an environment could be brought from other environments where they are grown. It is therefore, crystal clear that the natural environment (specifically the vegetation) determines what plants and/or crops and animals are available to any society as food.

However, not all plants and animals found in an environment are eaten by the people occupying it. Different groups of people select through time, those plants and animals they eat amongst those made available by the environment (Oluwabamide and Akpan 2005). This selection which is essentially borne out of experience and worldview explains the role of culture in food pattern. Thus, culture influences, to a larger extent, the food pattern of every society. It determines not only the type of foods consumed but the methods of processing or preparing them.

To understand the food patterns of any, community, therefore, the network of interactions between their environment and culture have to be examined (Storey 2002). Culture is significant since it is the basic phenomenon through which man exploits his environment for survival. A peoples method and degree of exploitation of their environment determine what food they eat. Thus, because of differences in cultural experiences food patterns differ from one society to the other (Roos et al. 2001).

This study therefore, examines the food pattern of two different peoples who are occupying similar environments. The essence is to identify the extent to which their food patterns are either different or similar. To this end, the Yoruba and Ibibio of South Western and South Eastern Nigeria respectively, are studied. Both occupy similar vegetations but their cultures are different. What of their food patterns? This study examines the extent to which the food patterns of the two societies are similar. The data were collected among the Yoruba people of Ondo state and the Ibibio people of Akwa Ibom state, in Nigeria.

\section{METHODOLOGY}

Qualitative data were collected using both interview and observation methods. A total of 240 interviewees were randomly selected at the proportion of 120 persons from each of the two societies being studied. An interview schedule was designed to facilitate a reliable data on relevant cultural traits in the two societies. Furthermore, the researchers observed the plants and animals available in each of the two societies and made a proper identification of those actually consumed by the people.

\section{Environmental and Cultural Settings}

The focus here in this study is the physical 
environment which is commonly associated with the topography. It includes the climate, drainage and vegetation. But essentially in this study, the vegetation of the two communities concerned as well as the food crops and animals in their environments are considered.

Both societies (Yoruba and Ibibio) fall within the same vegetational belts. These are the rain forest with tall trees and palm tress and the mangrove and fresh water swamp forest (Udoh 1970). Consequently, similar crops are grown in the two areas while similar animals survive in both. The crops include yams, bananas, rubber, cassava, palm products, cocoa, plantain, rice, soyabeans, cocoyams, pissava, maize, benniseed etc. The animals include fishes, cattle, pigs, goats, fowl etc. The culture of the Ibibio differs a great deal from that of the Yoruba. It is necessary at this juncture, to describe selected traits of their cultures.

The Yoruba occupy Ondo, Oyo, Ogun, Osun, Ekiti and Lagos states and parts of Kwara, Kogi and Edo States in South Western Nigeria. The basic social unit of Yoruba social organization is the lineage. A lineage sometimes covers the best part of a town, although it is more usual for a town to be made up of several lineages.

A Yoruba lineage consists of all persons claiming descent from the town founder. All the male members of the lineage, otherwise called agnates, reside in a compound established by the original founder. Living with them are their children and at times uncles and cousins. A woman of a lineage moves to her husband's compound at marriage but retain her lineage affiliation. Her own children are fully absorbed into their father's lineage which is usually an exogamous unit.

The Yoruba are generally patrilocal with respect to residence. That is, people tend to make permanent abode of and bring their wives at marriage to the father's compound in which they have stakes in such matters as inheritance and succession.

Yoruba traditional political system belongs to the category of centralized state systems as opposed to uncentralised systems sometimes referred to in anthropological literature as stateless or acephalous societies (Imoagene 1991). Infact, Lloyd (cited in Imoagene) refers to the Yoruba political institution as open representative government.

The Ibibio on the other hand, occupy Akwa
Ibom state and parts of the cross river state, in South eastern Nigeria. Among the Ibibio, kinship is patrilineal (i.e descent is traced through the father) while family is polygynous. According to Ekong (1988) the Ibibio family was initially patrilineal (upon marriage, a couple lives with or near the husbands parents) and recently neolocal (married couple lives apart from their relatives).

The Ibibio unit of social organization is the extended family (Ekpuk, Nung or Ufok). Generally, the people cannot conceive of the immediate nuclear family in isolation from the extended family.

The Ibibio traditional society operates a "stateless society" which, according to Ekong (1988), is organized on the segmnetary unilineal principles. Citing Onwuejeogwu, Ekong describes a stateless society as one which lacks a centralized system of political organization with a king ${ }^{7}$. The basic political unit among the Ibibio is the compound.

A compound consists of the head who is usually the eldest male, his wives, siblings and other relatives in the household. The compound head has jurisdiction over all the members of the household. However, he is subordinate to the head of the extended family. The extended family comprises of a combination of related compounds. This constitutes the extended family group. The extended family head handles serious matters affecting the lineage while the compound head handles purely domestic matters. Furthermore, a combination of extended family groups make up a clan which generally has a name, common dialect and custom, a totem and a ritual leader.

\section{RESULTS AND DISCUSSION}

From the above it is crystal clear that the Ibibio culture is quite different from that of the Yoruba. It is also obvious that both peoples- Ibibio and Yoruba-occupy similar environments. The question that easily comes to mind is, if the environments of the two societies are similar why are their cultures different?

As mentioned earlier, the differences in cultures were the consequences of differences in the peoples' (especially their progenitors') perception of their environments. It was also the consequences of differences in their experiences through time. For example, food patterns differ between the two communities being studied, 
though their natural environments which are similar provided the same sources of food. While there are a number of common food resources being explored by the peoples in the in the two cultures, there are still quite a number of others that differ markedly between them.

Table 1 indicates that certain plants and animals are eaten among both the Yoruba and Ibibio. Cassava, maize, yam plantain, goat, fish, chicken are found in both areas, but the extent to which they are eaten differs. Both groups eat cassava when processed into garri (farina) and $f u f u$ (fermented pounded cassava) forms. Fufu is not a stable food among the Yoruba but is very common among the Ibibio. Garri is a staple food in the two areas, yet the Ibibio eat it more than the Yoruba.

In both societies yam is either eaten as boiled or pounded yam. Both the Yoruba and Ibibio peoples eat pounded yam. Among a section of the Yoruba (especially those of Ekiti and Ondo States) pounded yam is a staple food for high social status persons. That is, it is more or less a prestige food. Among the Ibibio on the other hand, pounded yam is eaten but not as frequent as fufu and garri. It is not a prestige food rather a food that can be eaten by anyone regardless of class. Ibibio often eat pounded yam with a non-leafy soup known as "white soup" prepared with cocoyam whereas, fufu and garri are eaten with a variety of leafy soups. This explains why the later are eaten more frequently than pounded yam.

Both the Yoruba and the Ibibio eat plantain in variety of forms. While the Ibibio eat boiled

Table 1: Some foods (crops and animal) eaten in the two societies

\begin{tabular}{lcc}
\hline Foods (Crops \& Animals) & Yoruba & Ibibio \\
\hline Cassava & $\sqrt{ }$ & $\sqrt{ }$ \\
Maize & $\sqrt{ }$ & $\sqrt{ }$ \\
Yam & $\sqrt{ }$ & $\sqrt{ }$ \\
Plantain & $\sqrt{ }$ & $\sqrt{ }$ \\
Goat & $\sqrt{ }$ & $\sqrt{ }$ \\
Fish & $\sqrt{ }$ & $\sqrt{ }$ \\
Chicken & $\sqrt{ }$ & $\sqrt{ }$ \\
\hline
\end{tabular}

unriped plantain and plantain porridge the Yoruba eat the fried riped plantain in the form of chips. Often, the Yoruba combine it with boiled rice and stew or porridge beans. On the whole, the Ibibio consume plantain more than the Yoruba.

Both the Yoruba and Ibibio eat goat meat. The Ibibio often eat it in form of pepper soup which is combined with boiled rice. They also eat goat meat as part of soup. The Yoruba on the other hand, eat meat as part of either stew or soup. But on the whole, the Yoruba generally eat meat (goat and others) more frequently than the Ibibio. A typical Yoruba man would not eat stew or soup without a number of pieces of beef or other meats.

Similarly, both the Yoruba and Ibibio eat fish frequently. The Ibibio eat mostly smoked fishes while the Yoruba eat the unsmoked type. The Ibibio eat a great variety of smoked fishes of different grades. Quite a number of them are of the high grade, which are considered as prestigious. Yoruba only eat fresh fishes and most frequently, they are iced. The Ibibio relegates icedfishes; they do not frequently eat them.

Table 2 shows some plants producing leafy vegetables which the Ibibio eat as soup but the Yoruba do not eat. They include Gnetum africanum, Gongronema latifolium, Lasienthera Africana and Heinsia crinala. They are prepared into soups known in Ibibio as Afang soup, Utasi soup, Editan soup and Atama soup respectively. These vegetables grow in both the Ibibio and Yoruba communities, yet only Ibibio eat them. The major factor responsible for this is the differences in the cultural experiences of the two communities especially the people's perceptions of reality (world view).

There are other plant resources eaten in both communities but the parts eaten differ. Table two shows that piper guineensis is eaten by both the Yoruba and the Ibibio but part of the plant eaten differs. While the Ibibio eat the leaf, the Yoruba eat the seed.

Table 3 shows some leafy vegetables that form part of the Yoruba food, but are not eaten by the Ibibio. The Yoruba make soup with the leaves of

Table 2: Plants producing leafy vegetables in the two societies

\begin{tabular}{llcc}
\hline S. No. & Foods (Leafy vegetables) & Ibibio (Name of soup) & Yoruba \\
\hline 1 & Gnetum africanum & Afang soup & Not eaten \\
2 & Gongronema latifolium & Utasi soup & Not eaten \\
3 & Lasienthera Africana & Editan soup & Not eaten \\
4 & Heinsia crinala & Atama soup & Not eaten \\
5 & Piper guineensis & Odusa soup & Seed eaten \\
\hline
\end{tabular}


Table 3: Plants producing leafy vegetables and other soup condiments in the two communities

\begin{tabular}{lcc}
\hline Foods (crops) & Ibibio (Name of soup) & Yoruba (Name of soup) \\
\hline Spinard smosul & Not eaten & Tete soup \\
Schochoru oditorus & Not eaten & Ewedu soup \\
Parkia biglobosa & Not eaten & Iru seed (soup condiment) \\
Talanum triangulare & Water leaf & Leaf (rarely eaten) \\
\hline
\end{tabular}

Spinard Smosul and Schochorus Oditorus plants which they refer to as Tete and Ewedu respectively. The Ibibio on the other hand do not eat these plants. Furthermore, the Yoruba eat the seed of Parkia biglobosa as soup condiment while the Ibibio do no eat it at all. Both the Ibibio and the Yoruba eat the Talanum triangulare leaf. The Ibibio simply call it "water leaf" while the Yoruba call it Gbure.

The Ibibio eat Talanum triangulare more often than the Yoruba. Infact, it constitutes a fundamental content of virtually all Ibibio soups. It is always included in every vegetable soup. The Yoruba on the other, hand rarely eat it. In a typical Yoruba community the plant grows profusely and is considered as weed whereas among the Ibibio, it is grown in commercial quantities. It is highly demanded for through out the year. Hence, farmers engage in some irrigation during the dry season to cultivate it.

\section{CONCLUSION}

The environment provides a great lot of food resources (plants and animals) for man. Yet it is the responsibility of man to choose which of the resources to explore and exploit. Therefore, the types of food members of any society eat depend on a number of factors amongst which are the following:

Firstly, the available food resources. This is a function of the environment; that is the environment determines the types of plants that are grown in any society as well as the animals that can survive there.

Secondly, people's perception of their environment. This is a function of their cultural experience through time. Thus, a society chooses which food to eat amongst the multitude of plants and animals that the environment can support.

These and other factors explain why there are differences in food patterns among the societies of the world even those with similar physical environments. This study on the food patterns of two Nigerian societies (Yoruba and Ibibio) has shown that people living in similar environments do not necessary eat similar foods. This explains why quite a number of plants and animal resources exploited for food by the Ibibio are not exploited by the Yoruba even though they occupy similar natural environments.

\section{REFERENCES}

Arancenta J, Perez Rodrigo C, Ribas 1, Serra-Majem L 2003. Socio-demographic and Lifestyle Determinants of Food Patterns in Spanish Children and Adolescents: The Enkid Study. Eur J Clin Nutr, 57: $540-544$

Bajomo O 1998. The Yoruba of South West Nigeria: A Study on Nigerian Heritage. In: Stella O Babalola (Ed.): Fundamentals of Sociology. Lagos: Department of Sociology, Lagos State University, pp.1-12

Ekong EE 1983. Sociology of the Ibibio. Calabar: Scholars Press.

Imoagene O 1991. Know your country Series: The Yoruba of South Western Nigeria. Ibadan: New Era Educational Company.

Lien N, Jacobs DR, Klepp KI 2002. Exploring Predictors of Eating Behaviour among Adolescents by Gender and Socio-economic Status. Public Health Nutr, 5: 671-681.

Mishra G, Ball K, Arbuckle J, Crawford D 2002. Dietary Patterns of the Australian Adults and their Association with Socio-economic Status: Results from the 1995 National Nutrition Survey. Eur J Clin Nutr, 56: 687-693.

Oluwabamide AJ, Akpan NS 2005. Rural Poverty and Nutrition in Nigeria: A Case Study of Ikot Effiong community. Paper Presented During the $15^{\text {th }}$ Annual Conference of the Pan African Anthropological Association (PAAA). Yaounde Cameroon, August 8-12, 2005.

Onwuejeogwu MA 1975. The Social Anthropology of Africa: An Introduction. London: Heinemann.

Roos EB, Hivoronen V, Mikila S, Karvonen G, Rimpela M, 2001. Household Educational Level as a Determinant of Comsumption Raw Vegetables among Male and Female Adolescents. Pre Med, 33: 282291.

Schulze MB, Hoffman K, Kroke A, Boeing H 2003. An Approach To Construct Simplified Measures of Dietary Patterns for Explanatory Factor Analysis. Br J Nutr, 89: 409-419.

Storey M, Neumark-Sztainer D, French S 2002. Environmental Influences on Adolescent Eating Behaviours. J Amr Die Assoc, 102: S40-S51

Udo RK 1970 Geographical Regions of Nigeria. Lagos: African University Press. 